\title{
Pembelajaran Praktik Dalam Peningkatan Pemahaman Peserta Didik Mapel Fiqih di MTs Roudlotut Tholibin Kediri
}

\author{
Qurrotul Ainiyah \\ (q_ainiy@yahoo.com)

\section{STIT Al Urwatul Wutsqo Jombang}

\section{Ahmad Ari Tohari \\ STIT Al Urwatul Wutsqo Jombang}

\section{Abstract:}

The purpose of this research is to describe how the practical learning process is in increasing students understanding?, How to increase students' understanding through practical learning in class VIII Madrasah Tsanawiyah Roudlotut Tholibin Kediri?, What are the supporting and inhibiting factors in improving students' understanding through practical learning at Madrasah Tsanawiyah Roudlotut Tholibin Kediri ? This study uses a type of field research (fieldreasearch)and using a qualitative descriptive approach, with the design of data collection through interviews, observation and documentation. Furthermore, data analysis was carried out using descriptive qualitative analysis methods. It was found that: in class VIII MTs Roudlotut Tholibin Kediri used the practical method in order to improve student understanding, in each practice carried out through 3 stages, namely, the preparation stage, the implementation stage and the final stage in accordance with the learning implementation plan (RPP). then it was found that the impact of students who took part in practical learning activities had a high cognitive level compared to students who only studied material, there was also good interaction between teachers and teachers, teachers and students and students and students themselves. The supporting factors in practical learning are teachers, parents, environment, strength or cooperation between teachers, regulatory points. Meanwhile, the inhibiting factors are friends and students themselves. So, from the explanation above, it is proven that practical learning can improve students' understanding of maple fiqh class VIII MTs Roudlotut Tholibin.

Keywords: Practical Learning, Improve Understanding

\section{Pendahuluan}

Pada sisi lain pembelajaran mempunyai pengertian yang mirip dengan pengajaran, tetapi sebenarnya mempunyai konotasi yang berbeda. Dalam konteks pendidikan, guru mengajar agar peserta didik dapat belajar dan menguasai isi pelajaran hingga mencapai sesuatu objektif yang ditentukan (aspek kognitif), juga 
dapat memengaruhi perubahan sikap (aspek afektif), serta keterampilan (aspek psikomotor) seorang peserta didik, namun proses pengajaran ini memberi kesan hanya sebagai pekerjaan satu pihak, yaitu pekerjaan pengajar saja. Sedangkan pembelajaran menyiratkan adanya interaksi antara pengajar dengan peserta didik. ${ }^{1}$

Pembelajaran yang berkualitas sangat tergantung dari motivasi pelajar dan kreatifitas pengajar. Pembelajar yang memiliki motivasi tinggi ditunjang dengan pengajar yang mampu memfasilitasi motivasi tersebut akan membawa pada keberhasilan pencapaian target belajar. Target belajar dapat diukur melalui perubahan sikap dan kemampuan siswa melalui proses belajar. Desain pembelajaran yang baik, ditunjang fasilitas yang memandai, ditambah dengan kreatifitas guru akan membuat peserta didik lebih mudah mencapai target belajar. ${ }^{2}$

Berbicara tentang pendidikan, selalu menarik untuk kita ikuti perkembangannya secara up to date, sebab dalam kacamata edukasi tatanan sistem pembelajaran beserta komponen-komponen yang ada, tidak bisa dipandang hanya satu sudut saja, melainkan ada pengklasifikasian secara objek maupun subjek pengajaran terhadap kecerdasan intelektual, emosional maupun spiritual peserta didik. Pemerintah Indonesia telah menggariskan dasar-dasar, Tujuan Pendidikan dan Pengajaran dalam Undang-Undang No. 20 Tahun 2003 tentang Sistem Pendidikan Nasional. ${ }^{3}$

Pengertian pendidikan di atas menunjukkan bahwa tugas seorang pendidik adalah membantu peserta didik dalam mengembangkan potensi yang dimiliki anak didik, serta ikut berperan di dalam peningkatan keimanan dan ketakwaan juga membentuk kepribadian siswa baik secara lahir maupun batin. ${ }^{4}$ Untuk mencapai tujuan tersebut dibutuhkan sebuah metode yang bisa menggabungkan antara teori dengan praktik. Metode pembelajaran praktik adalah suatu metode dengan memberikan materi pendidikan baik menggunakan alat atau benda, seperti di peragakan, dengan harapan anak didik menjadi jelas dan mudah sekaligus dapat mempraktikkan materi yang dimaksud dan suatu saat di masyarakat. Metode ini memberikan jalan kepada para peserta didik untuk menerapkan, menguji dan menyesuaikan teori dengan kondisi sesungguhnya melalui paktik atau kerja, inilah peserta praktik atau latihan akan mendapatkan

${ }^{1} \mathrm{H}$ Abuddin Nata, Sejarah Pendidikan Islam (Kencana, 2014).

2 Moh Suardi, Belajar \& Pembelajaran (Deepublish, 2018).

${ }^{3}$ Mohammad Ali, Pendidikan Untuk Pembangunan Nasional: Menuju Bangsa Indonesia Yang Mandiri Dan Berdaya Saing Tinggi (Grasindo, 2009).

4 Layli Marhamah, "Kontribusi Guru Pendidikan Agama Islam Dalam Mengembangkan Kecerdasan Spiritual Siswa Di SD Bina Taruna III Kec. Medan Marelan," Kumpulan Karya Ilmiah Mahasiswa Fakultas Agama Islam Dan Humaniora 2, no. 02 (2020): 48. 
pelajaran yang sangat baik untuk mengembangkan dan menyempurnakan keterampilan yang di perlukan. ${ }^{5}$

Dekadensi pemahaman peserta didik dalam hal praktik saat ini serta minimnya pribadi yang mencerminkan seorang muslim, bukan terjadi dengan sendirinya melainkan ada asbab dan musabab yang membuat kemerosotan pemahaman pada siswa itu sendiri, meskipun secara eksistensi mereka berada di dunia pendidikan bahkan menjadi objek dalam mekanisme proses belajar mengajar, akan tetapi fenomena kekecewaan masyarakat pada suatu lembaga pendidikan, lagi-lagi menjadi trending topic di media massa maupun lingkup sosial pada umumnya, ketika anak yang di harapkan memiliki pemahaman yang luas serta pengalaman dalam mempraktekan ilmunya khususnya dalab bidang keagamaan malah yang terjadi sebaliknya. Fenomena demikian menjadi indikasi bahwasanya pendidikan masa millenial ini masih punya kekurangan dalam membentuk pribadi-pribadi yang cerdas, berpengalaman, berbudi luhur dan religius.

Pada dasarnya konsep pendidikan untuk mengembangkan pemahaman peserta didik dapat dengan baik di kembangkan ketika di sajikan dalam bentuk yang empiris. ${ }^{6}$ Siswa yang dihadapkan langsung pada miniatur sosial yang tersistem, beradaptasi dan berinteraksi dengan siswa atau peserta didik yang lainnya, peraturan-peraturan yang mengharuskan untuk ditaati serta, pembiasaan berperilaku positif dan pelatihan life skill untuk mengasah dan membekali peserta didik dikehidupan sosial bermasyarakat yang sebenarnya, terlingkup dalam ruang dan waktu yang lama, sehingga hal ini akan sangat efektif untuk mengembangkan segala potensi peserta didik apabila mereka berada di dalam sistem tersebut. Lingkungan Madrasah Tsanawiyah merupakan lembaga pendidikan yang telah menerapkan perihal di atas serta tidak sedikit yang mengkombinasikan antara sekolah formal dengan nonformal. ${ }^{7}$

Madrasah (sekolah) sebagai salah satu institusi atau lembaga pendidikan merupakan sarana melaksanakan pelayanan belajar dan proses pendidikan. Madrasah (sekolah) bukan hanya dijadikan sebagai tempat berkumpul antara guru dan peserta didik, melainkan suatu sistem yang sangat kompleks dan dinamis. Sekolah akan berfungsi dengan maksimal jika didukung oleh sistem manajemen yang terencana yang didukung sumber daya manusia (SDM) yang berkualitas,

\footnotetext{
${ }^{5}$ Izzatul Aini, "Hubungan Antara Metode Praktik Dengan Keterampilan Ranah Psikomotor Siswa Pada Mata Pelajaran Fiqih Di Madrasah Aliyah Negeri Sidoarjo" (UIN Sunan Ampel Surabaya, 2010).

6 Eddy Noviana, "Optimalisasi Pembelajaran Dalam Rangka Meningkatkan Profesionalisme Guru1," n.d.

${ }^{7}$ Kusworo Kusworo et al., “Pembaharuan Pembelajaran Pendidikan Ekonomi," 2019.
} 
sarana prasarana serta dana/ biaya pendidikan yang tepat. Penerapan peraturan dan sistem manajemen yang baku dalam lembaga pendidikan tentunya sangat dibutuhkan dalam upaya pemaksimalan potensi sekolah sehingga terciptalah pendidikan yang bermutu. Pendidikan yang bermutu di madrasah (sekolah) dapat tercapai melalui manajemen strategik dalam peningkatan mutu pendidikan.

Pengembangan kecerdasan pemahaman siswa atau peserta didik yang bernafas Islami perlu menjadi prioritas untuk dikaji secara baik dan mendalam, dalam hal ini Madasah Tsanawiyah Roudlotut Tholibin ini merupakan salah satu institusi pendidikan yang melakukan transmisi ilmu keagamaan dengan membimbing peserta didik mengembangkan pemahaman siswa lewat pembelajaran praktik dengan nuansa islami yang harapannya menjadi pribadi muslim yang peka terhadap sosial, berbudi luhur dan bertakwa kepada Allah SWT. serta mampu mengabdikan diri kepada masyarakat demi menegakkan syiar Islam. Maka sudah selayaknya pendidikan madrdasah tsanawiyah menjadi jalan alternative untuk proses pengembangan pribadi yang lebih baik, sopan dan peka terhadap lingkungan. ${ }^{8}$

Salah satu peran penting pendidikan untuk mengasah pemahaman mereka, mengajarkan bagaimana cara meninggalkan ketidaktahuan mereka serta bagaimana cara mengembangkan pemahaman mereka. Perkembangan pemahaman peserta didik sangat erat kaitannya dengan faktor lingkungan, diantaranya yaitu institusi pendidikan formal atau nonformal. Pendidikan selain memiliki peran urgen untuk mengasah intelektual juga menempati peran sebagai peningkatan pemahaman seorang peserta didik.

Pada kaitannya hal ini Madrasah Tsanawiyah Roudlotut Tholibin Kayen Kidul Kediri merupakan lembaga pendidikan yang kental dengan nuansa Islami, Berdasarkan hasil observasi yang dilakukan di Madrasah Tsanawiyah Roudlotut Tholibin pada tanggal 12-13 Agustus 2019. Madrasah Tsanawiyah ini berada di bawah naungan Yayasan KH. Sholihuddin Al-Qoyyuni Kediri LC. yang berdiri tanggal 30 Desember 2005 dan berlokasi di dalam lingkungan Pondok Pesantren Roudlotut Tholibin, perkampungan Kayen Kidul, kecamatan Kayen, kabupaten Kediri. Sekolah ini merupakan salah satu lembaga pendidikan formal yang dimiliki yayasan tersebut yang mengindu pada Departemen Pendidikan Nasional (Diknas).

Adapun model materi pembelajaran yang dipraktikkan di dalam lembaga Madrasah Tsanawiyah ini seperti baca Al-Qur'an sebelum mulai jam pelajaran pertama, shalat Dhuha dijam istirahat pertama, sholat dhuhur di jam istirahat

8 Solechan Program et al., "Pengembangan Kecerdasan Emosional Di Sma Primaganda Bulurejo Diwek Jombang," Ilmuna: Jurnal Studi Pendidikan Agama Islam 1, no. 2 (2019): 43-64, https://jurnal.stituwjombang.ac.id/index.php/ilmuna/article/view/108. 
kedua, shalat Jum'at dihari Jum'at, pelatihan sujud sukur dan sujud tilawah, puasa ramadhan, pelatihan zakat fitrah dan pelatihan haji (manasik haji). Ada beberapa faktor yang membuat peneliti tertarik dengan model pembelajaran praktik yang di lakukan oleh lembaga Madrasah Tsanawiyah Roudlotut Tholibin ini terhadap peserta didiknya guna peningkatan pemahaman para peserta didik. Proses kegiatan belajar mengajar motivasi para peserta didik atau siswa dalam hal pemahaman materi melalui praktik masih rendah. Kondisi ini dibuktikan dengan banyaknya siswa atau peserta didik yang pintar atau paham dalam hal materi akan tetapi masih mengalami kesulitan ketika memperagakan ilmu-ilmu yang mereka pelajari di dalam kelas. Kurangnya pemateri atau guru yang mengajarkan pembelajaran praktik, sehingga berpengaruh terhadap semangat peserta didik dalam memperdalam ilmu agama yang di kaji. Terfokus pada pembelajaran materi, sehingga terjadi minimnya pengetahuan peserta didik atau siswa dalam hal praktik.

\section{Hasil Penelitian dan Pembahasan}

\section{Pelaksanaan Pembelajaran Praktik dalam Mapel Fiqih Kelas VIII MTs Roudlotut Tholibin Kediri}

Perencanaan merupakan proses penyusunan sesuatu yang akan dilaksanakan untuk mencapai tujuan yang telah ditentukan. Pelaksanaan perencanaan tersebut dapat disusun berdasarkan kebutuhan dalam jangka waktu tertentu sesuai dengan keinginan pembuat perencanaan. Namun, yang lebih utama adalah perencanaan yang dibuat harus dapat dilaksanakan dengan mudah dan tepat sasaran. Begitu pula dengan perencanaan pembelajaran, Dalam rangka mengoptimalisasi proses belajar mengajar seorang guru berfungsi sebagai fasilitator yang harus mampu mengembangkan kemauan belajar anak, mengembangkan kondisi belajar yang relevan agar tercipta suasana belajar secara wajar dengan penuh kegembiraan dan mengadakan pembatasan positif terhadap dirinya sebagai seorang pengajar. Dan hal ini membutuh sebuah perencanaan pembelajaran yang baik yang disesuaikan dengan tujuan dan bahan ajar. ${ }^{9}$

Hasil penelitian menunjukkan bahwa guru Fiqih kelas VIII MTs Roudhotut Tholibin Kediri, khususnya guru mata pelajaran Fiqih, dalam mengajar selalu membuat perencanaan pembelajaran. Hal ini dirasa sangat penting guna memaksimalkan proses belajar mengajar di sekolah tersebut. Perencanaan yang disusun oleh Bapak Miftahul Ulum itu sebenarnya sudah sesuai karena sudah memiliki standar komponen serapan Kurikulum 2013, dan

\footnotetext{
${ }_{9}$ Isnawardatul Bararah, "Efektifitas Perencanaan Pembelajaran Dalam Pembelajaran Pendidikan Agama Islam Di Sekolah," Jurnal MUDARRISUNA: Media Kajian Pendidikan Agama Islam 7, no. 1 (September 24, 2017): 131-47, https://doi.org/10.22373/JM.V7I1.1913.
} 
pelaksanaan terhadap perencanaan yang dibuat oleh Bapak Miftahul Ulum juga sudah terlaksana dengan baik. Dari hasil lapangan menunjukkan bahwa rangkaian kegiatan selama ini berjalan sudah sesuai dengan perencanaan. Rencana pembelajaran dibuat sebagai acuan dasar pelaksanaan kegiatan pembelajaran, dan perencanaan dibuat serta digunakan sebagai prosedur pembelajaran Fiqih agar bisa berjalan dengan maksimal dan mampu mencapai tujuan pembelajaran. Sebagaimana teori yang dikemukakan oleh Kunandar yang menyatakan bahwa:

“Rencana pelaksanaan pembelajaran (RPP) adalah rencana yang menggambarkan prosedur dan pengorganisasian pembelajaran untuk mencapai satu kompetensi dasar yang ditetapkan dalam Standar Isi dan dijabarkan dalam silabusDengan menyusun rencana pembelajaran secara profesional, sistematis dan berdaya guna, maka guru akan mampu melihat, mengamati, mrnganalisis, dan memprediksi program pembelajaran sebagai kerangka kerja yang logis dan terencana". 10

Selanjutnya, agar pembelajaran bisa berhasil, seorang guru mempunyai peranan yang sangat penting dan harus memiliki berbagai macam kemampuan di antaranya memilih metode belajar mengajar yang tepat. Dalam hal ini proses pembelajaran Fiqih di kelas VIII MTs Roudlotut Tholibin Kediri menerapkan pembelajaran praktik sudah lama diterapkan dalam pembelajaran Fiqih di kelas VIII MTs Roudlotut Tholibin Kediri. Hal ini membawa dampak yang sangat baik bagi guru sekaligus siswa. Siswa dituntut untuk selalu aktif dalam setiap pembelajaran yang berlangsung agar tercipta suasana yang kondusif dan menyenangkan.

Dari hasil observasi yang peneliti lakukan diperoleh bahwa siswa cukup antusias dalam mengikuti kegiatan belajar mengajar. Siswa juga mulai berani mengajukan pertanyan serta berani mengemukakan pendapatnya. Dalam menerapkan pembelajaran praktik pertama-tama yang dilakukan oleh guru adalah memberi contoh motivasi kepada siswa baik melalui artikel atau berupa pemutaran video yang berkenaan dengan topik pembahasan pada hari itu. Hal ini untuk merangsang siswa agar siswa tertarik dan dapat berpartisipasi aktif dalam mengikuti kegiatan belajar mengajar.

Penerapan metode praktik dalam pembelajaran Fiqih di kelas VIII MTs Roudlotut Tholibin Kediri ini dapat mengembangkan potensi serta inisiatif dan tanggung jawab peserta didik. Hal ini sesuai dengan hasil penelitian

${ }^{10}$ Kunandar, Guru Profesional (Implementasi Kurikulum Timgkat Satuan Pendidikan Dan Sukses Dalam Sertifikasi Guru) (Jakarta: Raja Grafindo Persada, 2011). 
yang mengemukkan bahwa cara yang paling efektif untuk mengajarkan keterampilan adalah dengan demonstrasi. Tahap peragaan pada hakikatnya sudah merupakan tahap implementasi pembelajaran praktik. Pada tahap ini guru praktik harus mampu menyajikan peragaan yang menarik sehingga siswa memahami langkah-langkah kerja dan tahu apa yang harus dilakukannya. ${ }^{11}$

Terkait langkah-langkah pembelajaran praktik dalam pembelajaran Fiqih di kelas VIII MTs Roudlotut Tholibin Kediri. Hal tersebut juga senada dengan teori yang diungkapkan oleh Supardi terkait langkah-langkah penggunaan pembelajaran praktik adalah sebagai berikut:

a. Tahap persiapan:

1) Menetapkan tujuan demostrasi,

2) Menetapkan langkah-langkah demontrasi,

3) Siapkan alat atau benda yang dibutuhkan untuk demonstrasi.

b. Tahap pelaksanaan:

1) Mendemonstrasikan sesuatu sesuai dengan tujuan yang disertai dengan penjelasan lisan,

2) Memberi kesempatan kepada siswa untuk melakukan tanya jawab,

3) Memberi kesempatan kepada siswa untuk mencoba dan mempraktekkan.

c. Tahap tindak lanjut dan evaluasi

1) Menugaskan kepada siswa untuk mencoba dan memperaktekkan apa yang telah diperagakan,

2) Melakukan penilaian terhadap tugas yang telah diberikan dalam bentuk karya atau perbuatan. ${ }^{12}$

Proses pelaksanaan pembelajaran praktik dalam Mapel Fiqih kelas VIII MTs Roudlotut Tholibin Kediri telah diimplementasikan di kelas VIII MTs Roudlotut Tholibin Kediri dengan baik. Dalam usaha mengetahui tingkat keberhasilan proses belajar mengajar, ternyata aspek evaluasi merupakan salah satu bagian yang harus mendapatkan perhatian lebih. Sebab sebuah perencanaan pembelajaran akan dianggap baik jika telah dilakukan penilaian. Asumsinya adalah suatu perencanaan diuji dengan tujuan untuk mengetahui sejauh mana tingkat keberhasilan dari suatu program. Oleh

11 Titin Syahrowiyah, "Pengaruh Metode Pembelajaran Praktik Terhadap Motivasi Dan Hasil Belajar Pendidikan Agama Islam Siswa Kelas IV Sekolah Dasar," Studia Didaktika 10, no. 02 (2016): 1-18.

12 Aini, "Hubungan Antara Metode Praktik Dengan Keterampilan Ranah Psikomotor Siswa Pada Mata Pelajaran Fiqih Di Madrasah Aliyah Negeri Sidoarjo." 
karena itu, program pengajaranyang baik harus dapat dilaksanakan yang berujung pada pengujian tingkat evaluasi.

Hasil penelitian di Fiqih di kelas VIII MTs Roudlotut Tholibin Kediri menunjukkan bahwa setiap guru di sekolah tersebut memiliki keyakinan bahwa evaluasi adalah bagian yang tak terpisahkan dari proses pembelajaran itu sendiri. Hal ini dapat dibuktikan dengan sikap guru pada saat proses belajar mengajar berlangsung. Di setiap akhir pertemuan mereka selalu memberikan umpan balik (feed back) guna mengetahui kemampuan dan tingkat keberhasilan proses pembelajaran. ${ }^{13}$ Hasil belajar kognitif dan hasil belajar afektif akan menjadi hasil belajar psikomotor apabila peserta didik telah menunjukkan perilaku atau perbuatan tertentu sesuai dengan makna yang terkandung dalam ranah kognitif dan ranah afektif dengan materi kedisplinan menurut agama Islam. Jadi, pembentukan keterampilan motorik lebih tepat hanya dilakukan melalui kegiatan praktik. Melalui praktik yang berulang-ulang akan terbentuk kebiasaan-kebiasaan gerakan sekaligus akan menghasilkan keterampilan kerja yang lebih baik.14

Berdasarkan hasil proses pelaksanaan pembelajaran praktik dalam mapel Fiqih kelas VIII MTs Roudlotut Tholibin Kediri terkait metode pembelajaran di atas sesuai dengan teori yang diutarakan oleh Panjaitan (1983:29). Metode ini memberikan jalan kepada para peserta didik untuk menerapakan, menguji dan menyesuaikan teori dengan kondisi sesungguhnya melalui paktik atau kerja, peserta praktik atau latihan akan mendapatkan pelajaran yang sangat baik untuk mengembangkan dan menyempurnakan keterampilan yang diperlukan. Siswa melakukan latihan dengan tugas yang diberikan dengan tujuan untuk mengembangkan dan mendemonstrasikan keterampilan. kegiatan praktik memungkinkan siswa untuk lebih efektif terlibat dalam kegiatan belajar.

\section{Peningkatan Pemahaman Peserta Didik Melalui Pembelajaran Praktik dalam Mapel Fiqih Kelas VIII di MTs Roudlotut Tholibin Kediri}

Pembelajaran praktik dalam peningkatan pemahaman peserta didik pada mapel Fiqih di Kelas VIII MTs Roudlotut Tholibin Kediri. Hal ini dapat dibuktikan dengan adanya kerjasama, baik kerjasama antara siswa dengan

\footnotetext{
13 Yessy Nur Endah Sary, Buku Mata Ajar Evaluasi Pendidikan (Deepublish, 2018).

${ }^{14}$ Hesti Yulianti, Cecep Darul Iwan, and Saeful Millah, "Penerapan Metode Giving Question and Getting Answer Untuk Meningkatkan Hasil Belajar Peserta Didik Pada Mata Pelajaran Pendidikan Agama Islam," Jurnal Penelitian Pendidikan Islam 6, no. 2 (November 15, 2018): 197, https://doi.org/10.36667/JPPI.V6I2.297.
} 
guru, maupun kerjasama antara siswa dengan siswa. Dengan adanya kekompakan dan keharmonisan tersebut dapat menciptakan suasana pembelajaran yang kondusif dan menyenangkan. Adanya pembelajaran yang menyenangkan dapat membantu siswa dalam menyerap dan memahami pelajaran yang diberikan oleh guru dengan menggunakan metode-metode yang variatif serta pembentukan suasana kelas yang menarik.

Penggunaan metode praktik dalam pembelajaran Fiqih dianggap dapat meningkatkan kualitas pembelajaran Pendidikan Agama Islam karena pembelajarannya yang efektif dan lebih memberdayakan potensi siswa. Sehingga dengan mudah guru dapat mencapai target kurikulum yang telah ditentukan dan dapat meningkatkan prestasi siswa yang selama ini dijadikan tolak ukur keberhasilan Pendidikan Agama Islam. ${ }^{15}$

Metode praktik yang diterapkan dapat meningkatkan kualitas pembelajaran Pendidikan Agama Islam karena di dalam pembelajaran dengan menggunakan metode tersebut terdapat beberapa unsur, di antaranya:

a. Pengalaman, dengan metode ini peserta didik mendapatkan pengalaman langsung dengan mengaktifkan lebih banyak indra dari pada cuma mendengarkan

b. Pemahaman siswa berupa kesanggupan siswa untuk dapat mendefinisikan sesuatu dan mengusai hal tersebut dengan memahami makna tersebut. Dengan demikian pemahaman merupakan kemampuan dalam memaknai hal-hal yang terkandung dalam suatu teori maupun konsep-konsep yang dipelajari.

Dari hasil lapangan menunjukkan bahwa secara umum metode praktik yang diterapkan dapat meningkatkan kualitas pembelajaran utamanya dalam meningkatkan pemahaman siswa pada mapel Fiqih di Kelas VIII MTs Roudlotut Tholibin Kediri dan telah diimplementasikan di kelas VIII MTs Roudlotut Tholibin Kediri dengan baik berikut dengan indikatornya. Sebagaimana teori yang dikemukakan oleh Tohirin yang menjelaskan bahwa pemahaman dapat dibedakan dalam tiga tingkatan:

1) Pemahaman terjemahan yakni kesanggupan memahami makna yang terkandung di dalamnya.

2) Pemahaman penafsiran, misalnya membedakan dua konsep yang berbeda.

${ }^{15}$ Marhamah Saleh, "Strategi Pembelajaran Fiqh Dengan Problem-Based Learning," Jurnal Ilmiah Didaktika: Media Ilmiah Pendidikan Dan Pengajaran 14, no. 1 (August 1, 2013): 190-220, https://doi.org/10.22373/JID.V14I1.497. 
3) Pemahaman estrapolasi yakni kesanggupan melihat di balik yang tertulis, tersirat dan tersurat, meramalkan sesuatu dan memperluaskan wawasan.

Sejalan dengan pendapat tersebut Sudjana juga mengelompokkan pemahaman ke dalam tiga kategori yaitu sebagai berikut:

1) Tingkat terendah. Pemahaman tingkat terendah adalah pemahaman terjemahan.

2) Tingkat kedua. Pemahaman penafsiran adalah menghubungkan bagian-bagian terdahulu dengan yang diketahui berikutnya, atau menghubungkan beberapa bagian dari grafik dengan kejadian, membedakan yang pokok dan yang bukan pokok.

3) Pemahaman tingkat ketiga. Pemahaman tingkat ketiga atau tingkat tertinggi adala pemahaman ekstrapolasi. Dengan ekstrapolasi diharapkan seorang mampu melihat balik yang tertulis, dapat membuat ramalan tentang konsekuensi atau dapat memperluas persepsi dalam arti waktu, dimensi, kasus, ataupun masalahnya. ${ }^{16}$

Unsur tersebut juga didukung dengan adanya sikap dan perilaku guru serta ruang kelas yang menunjang aktif. Kesemuanya itu tidak dapat dipisahkan Karena satu sama lain saling mempengaruhi dan saling mendukung antara satu dengan yang lain. Hal lain yang patut dijadikan acuan untuk mengetahui peningkatan kualitas pembelajaran adalah sistem penilaian. Dalam sistem penilaian di kelas VIII MTs Roudlotut Tholibin Kediri, terdapat tiga komponen yang perlu diperhatikan, di antaranya adalah komponen kognitif, afektif dan psikomotorik. Oleh karena itu untuk menilai hasil evaluasi yang mengarah pada kognitif, afektif dan psikomotorik perlu adanya patokan atau penilaian yang disebut Kriteria Ketuntasan Minimal (KKM), adapun dalam pembelajaran Fiqih di VIII MTs Roudlotut Tholibin Kediri menggunakan KKM dengan rata-rata nilai 75. Artinya siswa yang mempunyai nilai 75 ke atas dinyatakan lulus atau berhasil dalam mengikuti pembelajaran. Sedangkan siswa yang mempunyai nilai 74 ke bawah dinyatakan belum tuntas. Sehingga perlu dilakukan pendalaman materi lebih lanjut dan mengikuti remidial.

Selain itu, hasil penelitian menunjukkan, bahwa penerapan metode praktik dalam pembelajaran Fiqih, mempunyai efektifitas yang cukup besar.

${ }^{16}$ Mukhsin SMA Negeri and Kabupaten Kotabaru, “Meningkatkan Pemahaman Dan Hasil Belajar Peserta Didik Pada Materi Limit Fungsi Trigonometri Melalui Pendekatan Pembelajaran Discovery Learning Di Kelas Xii Ips 4 Sma Negeri 2 Kotabaru Semester 1 Tahun Pelajaran 2019/2020," CENDEKIA: JURNAL ILMIAH PENDIDIKAN 9, no. 1 (March 29, 2021): 113-25, https:/ / doi.org/10.33659/CIP.V9I1.193. 
Hal ini terbukti tidak saja dengan pencapaian materi pembelajaran yang secara kuantitatif ditunjukkan dengan nilai tes yang bagus, atau secara kualitatif dibuktikan dengan ketertarikan para siswa kepada proses pembelajaran hingga kemudian melahirkan motivasi untuk mempelajari materi pelajaran. Dengan berpijak pada pemahaman bahwa pembelajaran Fiqih yang berkualitas adalah pembelajaran tersebut mampu memenuhi target kompetensi, baik dari aspek kognitif, afektif dan psikomotorik.

Berdasarkan hasil di lapangan terkait peningkatan pemahaman peserta didik melalui pembelajaran praktik dalam mapel Fiqih kelas VIII di MTs Roudlotut Tholibin Kediri di atas sesuai dengan teori yang diutarakan oleh Kemendiknas, dasar pendidikan karakter terdapat dalam UU No. 20 tahun 2003 tentang Sisdiknas Pasal 3. Undang-Undang Republik Indonesia No. 20 tahun 2003 tentang Sistem Pendidikan Nasional (UU Sisdiknas) merumuskan fungsi dan tujuan pendidikan nasional yang harus digunakan dalam mengembangkan upaya pendidikan di Indonesia. Pasal 3 UU Sisdiknas menyatakan bahwa: "Pendidikan nasional berfungsi mengembangkan dan membentuk watak serta peradaban bangsa yang bermartabat dalam rangka mencerdaskan kehidupan bangsa, bertujuan untuk berkembangnya potensi peserta didik agar menjadi manusia yang beriman dan bertakwa kepada Tuhan Yang Maha Esa, berakhlak mulia, sehat, berilmu, cakap, kreatif, mandiri, dan menjadi warga negara yang demokratis serta bertanggung jawab."

3. Faktor Pendukung dan Penghambat dalam Peningkatan Pemahaman Peserta Didik Melalui Pembelajaran Praktik Mapel Fiqih Kelas VIII MTs Roudlotut Tholibin Kediri

a. Analisis Faktor Pendukung dalam Peningkatan Pemahaman Peserta Didik Melalui Pembelajaran Praktik dalam Mapel Fiqih Kelas VIII di MTs Roudlotut Tholibin Kediri

1) Guru

Karena guru yang merencanakan tujuan belajar peserta didik menuju ke arah mana, mengorganisir berbagai sumber belajar untuk mewujudkan tujuan belajar, memimpin yang meliputi memberikan motivasi, mendorong dan memberikan stimulus pada siswa serta mengawasi segala sesuatu mulai dari berjalanya kegiatan pembelajaran praktik sampai selesai, ${ }^{17}$ apakah sudah berjalan sebagaimana mestinya atau belum dalam rangka pencapaian tujuan

17 Rina Febriana, Kompetensi Guru (Bumi Aksara, 2021). 
dari kegiatan pembelajaran praktik dalam penongkatan pemahaman peserta didik mapel Fiqih kelas VIII MTs Roudlotut Tholibin.

2) Orang Tua

Orang tua atau wali murid sendiri yang menginginkan ketika anaknya atau peserta didik lulus nanti mereka berharap anakanaknya tidak hanya faham tentang materi pelajaran tetapi juga faham dan mengerti bagaimana cara mempraktikanya, khususnya dalam bidang Fiqih mengenai ubudiyah yang akan mereka terapkan di masyarakat sehingga menjadi insan yang bermanfaat bagi umat, agama, dan negara.

3) Lingkungan

Karena MTs Roudlotut Tholibin Kediri ini erat kaitanya dengan dunia pesantren, maka kegiatan sehari-hari anak pesantren ini di lihat langsung oleh peserta didik di MTs Roudlotut Tholibin, sehingga menumbuhkan minat dan memotivasi para peserta didik untuk turut bersaing dalam hal kependidikan khususnya pada ubudiyah Fiqih yang akan mereka lalui pada pembelajaran berbasis praktik.

4) Kekuatan atau Kerjasama Antara Guru

Melalui kekuatan atau kerjasama antara para guru yang ikut serta mensukseskan program kegiatan pembelajaran praktik akan lebih mudah untuk bersama-sama membangunkan, mengembangkan, memajukan, merubah atau memperbaiki serta meningkatkan pemahaman peserta didik melalui metode pembelajaran praktik. ${ }^{18}$

5) Poin-Poin Peraturan

Peraturan-peraturan yang diterapkan di lembaga MTs Roudlotut Tholibin Kediri sangat menguatkan dan mengarahkan peserta didik atau siswa untuk mengikuti kegiatan pembelajaran praktik. Peraturan-peraturan disini juga melatih mental kepada para siswa agar membiasakan diri untuk menjalankan peritah dan menjauhi larangan yang ada di madrasah supaya terhindar dari sanksi. Selain memberikan efek jera kepada peserta didik, lembaga ini juga memberikan reward kepada peserta didik guna untuk menambah semangat peseta didik.

b. Analisis Faktor Penghambat dalam Peningkatan Pemahaman Peserta Didik Melalui Pembelajaran Praktik dalam Mapel Fiqih Kelas VIII di MTsRoudlotut Tholibin Kediri

${ }^{18}$ H Muh Arif, Profesi Kependidikan: Pedoman Dan Acuan Guru Mencintai Profesinya (Insan Cendekia Mandiri, 2020). 
1) Teman

Teman yang memiliki kepribadian yang buruk, sering gaduh ketika proses kegiatan belajar mengajar berlangsung akan menjadi penghambat bagi peserta didik lain yang dengan sungguh-sungguh mengikuti kegiatan pembelajaran praktik, sehingga mengganggu proses peningkatan pemahaman untuk para siswa. ${ }^{19}$

2) Siswa

Siswa yang memiliki tingkat kesadaran yang rendah menjadi penghambat pada kegiatan pembelajaran praktik karena susah untuk dikondisikan sehingga mengganggu konsentrasi dari peserta didik yang lain, juga sering merasa sedikit bosan dan menganggap pembelajaran praktik bersifat

\section{Kesimpulan.}

Proses pembelajaran praktik dalam mapel Fiqih kelas VIII Madrasah Tsanawiyah Roudlotut Tholibin Kediri yaitu praktik sujud diluar sholat (sujud syukur dan sujud tilawah), praktik sholat tarawih, dan praktik zakat fitrah Semua praktik yang dilaksanakan diatas melalui 3 proses yaitu tahap persiapan, tahap pelaksaan dan tahap akhir yang tertuang dalam rencana pelaksanaan pembelajaran (RPP). Peningkatan pemahaman peserta didik melalui pembelajaran praktik dalam mapel Fiqih kelas VIII di Madrasah Tsanawiyah Roudlotut Tholibin Kediri ini dapat dilihat berdasarkan kerjasama, yang menggambarkan adanya kekompakan dan keharmonisan antar mereka. siswa untuk lebih mudah dalam menyerap dan memahami pelajaran. Pembelajaran yang berlangsung lebih efektif dan lebih memberdayakan potensi peserta didik. Guru dapat mencapai target kurikulum sesuai dengan yang telah ditentukan. Prestasi siswa semakin meningkat. Hal ini terbukti dengan meningkatnya nilai hasil tes yang diberikan oleh guru kepada mereka.Faktor pendukung dan penghambat dalam peningkatan pemahaman peserta didik melalui pembelajaran praktik dalam mapel Fiqih kelas VIII di Madrasah Tsanawiyah Roudlotut Tholibin Kediri adalah sebagai berikut : Faktor pendukung pada pembelajaran praktik Guru, Orang tua, Lingkungan islami, Kekuatan atau kerjasama antara guru, Poin-poin peraturan dan siswa. Adapun Faktor penghambat pada pembelajaran praktik dalam peningkatan pemahaman peserta didik mapel Fiqih kelas VIII MTs Roudlotut Tholibin adalah Teman dan Siswa sendiri.

19 Eni Fariyatul Fahyuni and Istikomah Istikomah, “Psikologi Belajar \& Mengajar (Kunci Sukses Guru Dalam Interaksi Edukatif)” (Nizamia Learning Center, 2016). 


\section{Daftar Pustaka}

Aini, Izzatul. "Hubungan Antara Metode Praktik Dengan Keterampilan Ranah Psikomotor Siswa Pada Mata Pelajaran Fiqih Di Madrasah Aliyah Negeri Sidoarjo." UIN Sunan Ampel Surabaya, 2010.

Ali, Mohammad. Pendidikan Untuk Pembangunan Nasional: Menuju Bangsa Indonesia Yang Mandiri Dan Berdaya Saing Tinggi. Grasindo, 2009.

Arif, H Muh. Profesi Kependidikan: Pedoman Dan Acuan Guru Mencintai Profesinya. Insan Cendekia Mandiri, 2020.

Bararah, Isnawardatul. "Efektifitas Perencanaan Pembelajaran Dalam Pembelajaran Pendidikan Agama Islam Di Sekolah." Jurnal MUDARRISUNA: Media Kajian Pendidikan Agama Islam 7, no. 1 (September 24, 2017): 131-47. https://doi.org/10.22373/JM.V7I1.1913.

Fahyuni, Eni Fariyatul, and Istikomah Istikomah. "Psikologi Belajar \& Mengajar (Kunci Sukses Guru Dalam Interaksi Edukatif)." Nizamia Learning Center, 2016.

Febriana, Rina. Kompetensi Guru. Bumi Aksara, 2021.

Kunandar. Guru Profesional (Implementasi Kurikulum Timgkat Satuan Pendidikan Dan Sukses Dalam Sertifikasi Guru). Jakarta: Raja Grafindo Persada, 2111.

Kusworo, Kusworo, Rusmaini Rusmaini, Badrus Sholeh, and Fitra Jaya. "Pembaharuan Pembelajaran Pendidikan Ekonomi," 2019.

Marhamah, Layli. "Kontribusi Guru Pendidikan Agama Islam Dalam Mengembangkan Kecerdasan Spiritual Siswa Di SD Bina Taruna III Kec. Medan Marelan." Kumpulan Karya Ilmiah Mahasiswa Fakultas Agama Islam Dan Humaniora 2, no. 02 (2020): 48.

Nata, H Abuddin. Sejarah Pendidikan Islam. Kencana, 2014.

Noviana, Eddy. "Optimalisasi Pembelajaran Dalam Rangka Meningkatkan Profesionalisme Guru1," n.d.

Program, Solechan, Studi Pendidikan, Agama Islam, Stit Al Urwatul, Wutsqo Jombang, and Zidni Zidan Program. "PENGEMBANGAN KECERDASAN EMOSIONAL DI SMA PRIMAGANDA BULUREJO DIWEK JOMBANG." Ilmuna: Jurnal Studi Pendidikan Agama Islam 1, no. 2 (2019): 43-64. https://jurnal.stituwjombang.ac.id/index.php/ilmuna/article/view/108.

Saleh, Marhamah. "STRATEGI PEMBELAJARAN FIQH DENGAN PROBLEMBASED LEARNING." JURNAL ILMIAH DIDAKTIKA: Media Ilmiah Pendidikan Dan Pengajaran 14, no. 1 (August 1, 2013): 190-220. https:// doi.org/10.22373/JID.V14I1.497.

Sary, Yessy Nur Endah. Buku Mata Ajar Evaluasi Pendidikan. Deepublish, 2018.

SMA Negeri, Mukhsin, and Kabupaten Kotabaru. "Meningkatkan Pemahaman Dan Hasil Belajar Peserta Didik Pada Materi Limit Fungsi Trigonometri Melalui Pendekatan Pembelajaran Discovery Learning Di Kelas Xii Ips 4 Sma Negeri 2 Kotabaru Semester 1 Tahun Pelajaran 2019/2020." Cendekia: Jurnal Ilmiah Pendidikan 9, no. 1 (March 29, 2021): 113-25. https://doi.org/10.33659/CIP.V9I1.193. 
Suardi, Moh. Belajar E Pembelajaran. Deepublish, 2018.

Syahrowiyah, Titin. "Pengaruh Metode Pembelajaran Praktik Terhadap Motivasi Dan Hasil Belajar Pendidikan Agama Islam Siswa Kelas IV Sekolah Dasar." Studia Didaktika 10, no. 02 (2016): 1-18.

Yulianti, Hesti, Cecep Darul Iwan, and Saeful Millah. “Penerapan Metode Giving Question and Getting Answer Untuk Meningkatkan Hasil Belajar Peserta Didik Pada Mata Pelajaran Pendidikan Agama Islam." Jurnal Penelitian Pendidikan Islam 6, no. 2 (November 15, 2018): 197. https://doi.org/10.36667/JPPI.V6I2.297. 